\title{
Attitude Scale Towards Flirting Violence
}

\author{
Fatma Erva Tayanç ${ }^{1}$, Merve Sarıer ${ }^{2}$, Cansu Uysal ${ }^{3}$, Harun Kamanlı ${ }^{4}$ \\ ${ }^{1}$ TED University, Department of Guidance and Psychological Counseling, \\ Ziya Gökalp 47-48, 06420 Ankara/Turkey \\ 2 TED University, Department of Guidance and Psychological Counseling, \\ Ziya Gökalp 47-48, 06420 Ankara/Turkey \\ ${ }^{3}$ TED University, Department of Guidance and Psychological Counseling, \\ Ziya Gökalp 47-48, 06420 Ankara/Turkey \\ ${ }^{4}$ TED University, Department of Guidance and Psychological Counseling, \\ Ziya Gökalp 47-48, 06420 Ankara/Turkey
}

\begin{abstract}
:
The aim of this study was to develop an attitude scale towards flirting violence for university students who study at TED University. 232 university students aged 18-25 in Ankara participated in this study. University Students' Attitudes Scale Towards Flirting Violence (ASTFV)" is a 5 item Likert type scale. Exploratory factor analysis and confirmatory factor analysis was used for validity and the results of the factor analysis indicated that the scale explains $62,798 \%$ of the total variance. For reliability Cronbach Alpha coefficient was 0.938 . Findings indicated that the ASTFV was a valid and reliable scale.
\end{abstract}

Keywords: University students, flirting violence scale, violence, attitudes toward violence

\section{Introduction}

One of the concepts of violence (sociology, biology, psychology, religion, philosophy, law, law, education, health, etc.) that can take place in different disciplines is a flirting violence which is one of the contemporary concepts. Flirting violence appears especially at the age of adolescence which is the period that people behave without knowing cultural, economic and geographical boundaries as a form of human rights violation and discrimination.

During relationship process partners may have different or opposite ideas or situations in terms of; socioeconomic variables, education, intellectualunity and perspective (place of birth, age difference, choice of profession, religion social activities social media using style etc.). Flirting violence is the types of violence which the result of these situations that 1 Violence appears in the attitudes of partners towards each other. Types of violence are: Psychological violence, Verbal Violence, Sexual Violence, Behavioral Violence, Symbolic Violence, Physical Violence, Economic violence, Work Place Violence (mobbing) Technology Violence, Stalking Violence Social Flirting Violence and Digital Flirting Violence. As a result, flirting violence might be defined as controlling, empowering, suppressing, communicating, and feeling worthless in the communication or perceptions that are possible to apply to each other, such as the application of only one partner.

Romantic relationships in university years play an important role in the development of the individual. Addressing the violence between couples flirting in Turkey is very new limited topic. For identification of the violence attitude severity and identification of the risk groups are important to develop. That's why, in this study, it was aimed to develop a scale to identify students' attitudes towards flirting violence to be a suitable and reliable scale for Turkish society.

The reliability coefficients obtained show that this scale is reliable. As a result of the reliability and validity analyzes, "Attitude Scale Towards Flirting" consisting of 45 items and 7 sub-factors was developed. It is hoped that this scale which has been developed in this direction, will contribute towards the change of students' flirting attitudes.

\section{Literature Review}

The phenomenon of violence that emerges with the existence of mankind can manifest itself in many complex forms. With these complex forms; we are faced with individual and social dimension. As it is understood from this, it is not easy to define the word violence. Pressure, persecution, intimidation, 
intimidation, killing, punishment, rebellion; regardless of its main characteristics, changes its frequency with respect to time and collection. In this context, the aggression that exists on the basis of violence is directly related to the force. These associations also emphasized that the cases of 'violence' and 'aggression' are not independent of each other and should be evaluated together (Kocac1k,2001). Physiology such as starvation, thirst, or lack of fulfilment of spiritual needs such as love, interest, touch can make a person aggressive (Anatolian Journal of Psychiatry 2007; 8:206-214). The reason for the emergence of these aggression behaviours, the direction, size and nature of their emergence brought different definitions about violence and it was based on different bases in the evaluation of aggression movements observed in humans.

In studies conducted, the concept of violence occurs most frequently in adolescence and is most likely to be exposed during this period, which suggests that aggressiveness may be a potential step in childhood adulthood (Subasi N, Akın A., 2003.231-248), because the adolescent tries to win his own identity while searching for the answer "I am who". During this acquisition, the adolescent may exhibit negative behaviours due to the complexities it confronts. These behaviours can sometimes evolve into aggression. It is more likely to observe the aggression dimension as the destruction or hurt of more objects or persons in these age ranges, and the advanced dimensions are diversified as joining the gang (Lopez \& Emmer, 2002).

\section{THEORIES ON VIOLENCE AND AGRESSION}

Aggression and violence are the most important and current problems that are encountered and investigated in adolescents and tried to be solved by methods such as psycho-education, group counselling, cognitive-behavioural group therapy, psychodrama, psychological counselling with speeding group from the consultant.

On the basis of all these studies, firstly various theories about the causes of aggression are emphasized. The diversity of theories explaining aggression-violence is classified as follows;

a-Biological Based Theories

b-Instinct Theories: Psychoanalytic Theories and Ethology Theory

c-Frustration-Aggression Theory

d-Aggression Theories Explaining Learning

Behaviour:

Classic Conditioning

Operational Conditioning

Social Learning Theory

\section{Cognitive Theories}

e-Ecological Theory

The adoption of the view that aggression is an innate instinct in the psychoanalytic theory has been the predecessor of Freud. According to Freud, aggression is not a docile and gregarious entity that protects itself only when it is attacked, but actually looking for love. High-level aggression must be seen as part of its instinctual nature (Freud, S. 1971, Trans., Budak, 1994). This has brought three separate explanations. In the first stage, he tried to explain the neurotic contradictions in general, taking care of the libido and psychosexual development processes instead of aggression. In the second phase, Freud concentrated on ego-instincts. Thus, sexual instincts and ego-instincts are treated as two types of instinct. Aggression has an important role because ego-intuition tends to protect itself. For this reason, aggression is considered as part of the ego-internal motives rather than libido. In the last phase, Freud fell into contradiction in his views and united all instincts into two classes as sexual instincts and selfprotection instinct. These are the instincts of life (Eros) and eternal (Thanatos). While the life instinct aims to reduce sexual tension, the death instinct aims to purify itself from the life stress. According to Bronfenbrenner's ecological foundation; the best way to understand the relationship between aggression and violence is ecological theory.

Ecological foundations are influenced by personal, family, environmental and social factors that each person has. These concepts trigger aggression and violence. Bronfenbrenner (1986) notes that human development occurs as a result of interaction of individual and environmental characteristics.

Bronfenbrenner (1986) lists these as individual factors, family factors, school and peer factors, social factors and situation-specific factors. These factors are considered as risk factors associated with aggression. In Bronfenbrenner's theory of ecological systems, violence can be viewed from another angle. In theory, the individual and environmental characteristics of human development are emphasized and individual factors, family factors, school and peer factors, social factors and situationspecific factors can be emphasized as risk factors related to aggression (Merttürk, 2005, 3).

Studies which are made contact between aggression and learning are asserted by Bandura. Having violence attitudes of individuals who are role model by children affect this topic. If individual who is role model have attitudes which are related to violence, children learn these attitudes and they become to apply these attitudes. On the contrary, in 
observing by model, not having attitudes which are related to violence of children is not believed (Freedman, Sears \& Carlsmith, 1989: 208).

Bandura and Walters emphasize that how to develop and how to learn of aggression. According to theory, learning is occurred by three environmental events which are family activities, cultural activities and symbolic model. Also, aggression occur to observe of model's behaviours and it continues with effects of reinforces. As an example, Bobo Doll experiment of Bandura is applied. As a result of this experiment, Bandura underscores that learning everything directly of individuals are not necessary. They might learn lots of things to observe other's experiences. Especially, children who are at primary school might acquire lots of behaviour which are related to cognitive, social, psychomotor and moral value with examples of suitable model.

Behavioural approach might be explained with operant conditioning and classical conditioning. In behavioural approach, some ideas focus on the fact that the learning of the aggression of people or organisms will be effective in this process. Also, according to Johnson, there are some similarities between frustration- aggression theory and classical conditioning. In frustration- aggression theory, frustration is an unconditional stimulus because the individual in the face of frustration can act aggressively in any case unconditionally. While aggression is innate and unavoidable impulse according to instinct theory, aggression is an impulse against obstacles which encounter during obtaining goals and fulfilling needs.

Ideas of Adler are related to aggression begin at the beginning of the 20. century. Adler's views on this issue are very close to the views of contemporary psychoanalytic. According to Adler, aggression means that is an impulse to meet all need of people. Adler thinks that anxiety is an aggression against individual's self. Later, instead of an instinct, Adler mentions that aggression is counterintuitive behaviours. Also, the aggression instinct can be directed in various ways, to someone else or to the individual itself. While Adler indicates that a wrathful fighting is an example of pure aggression, later, behaviours in sport and war is remarked as a kind of aggression. In the later years, Adler gives less importance to aggression and it is a natural reaction against obstacles in daily life rather than an instinct.

\section{Method}

During scale development stage, SPSS statistical program was used for data analysis. The validity of the draft scale was examined when validity and reliability analyses were conducted. Then the factor analysis is done for evaluating structure validity. After factor analysis every item's, sub title's which are: psychological violence, verbal violence, behavioural violence, physical violence, economic violence, social flirting violence and social media violence and the whole scale's reliability analysis are done. For reaching more meaningful interpretations Varimax Rotation which is provide sensitive and most frequent distinctions. On the leadership of the Assistant Professor Doctor Olcay Y1lmaz the scope validity study has been conducted to determine the extent to which the items in this measure represent the behaviours to be measured and to determine the suitability of the measures. The study sample consisted of 232 TED University Student who are between 18- 25 years old. It is estimated that 150 students are girls and 82 students are boys. 100 variables pool were developed in direction of literature review and focus group survey along with expert opinion who is Assistant Professor Doctor Olcay Yilmaz. Data were analysed by using SPSS outcome's correlations, KMO values, Communalities values, Variance explained, Scree plot graph, Item-factor loadings which depends on results of Likert Scale. Study conducted on voluntary participant in online platforms. The study was developed methodologically in order to develop the Scale which is Attitude Towards to Flirting Violence. This research made real with students who study at TED University Faculty of Education. In first stage literature review is done with searching relevant materials then, item pool is occurred as 3.8 times of items which get place in scale, five students are chosen for sampling for each item. After sampling study number of items decreased to 45 from 100 with varimax rotation and 12 items are changed according to view of expert and results of SPSS outcomes. Then, according to Likert Scale each item is ordered 1 to 5. (1: Totally Disagree, 2: Partly Disagree, 3: Not Sure, 4: Partly Agree, 5: Totally Agree). According to results of the attitude scale individuals who shows tendency to 5 means that individual's attitudes towards to flirting violence is supports flirting violence. If participant's result show tendency to 1 it means, participant's attitudes are do not support flirting violence. Total score is 225 . High score is over 113 scores and it means positive attitude of flirting violence. Low score is below 113 and it means negative attitude of flirting violence.

\section{Analyzing Of Data}

During the developing scale, spss 24 statistical programme is used to analyse data in scale form. 
While validity and reliability analysis implement; firstly, content validity of sketch scale is examined, after that factor analysis process is made to construct validity. After the factor analysis, reliability analysis is made. For testing of construct validity, factor analysis is applied. KMO and Bartlett's Test is applied to identify suitability to principle component analysis of data and samples. In order to interpret more better, varimax rotation which are most frequently used, and the best discrimination is applied. Eigenvalue is 1.00 for identifying number of factors. while identifying items which take part at scale, total item correlation is used. Internal Consistency Value and Half Split Reliability is used to calculate reliability of scale.

\section{Findings Related To Validity Of Scale}

Content validity: Expert opinions are appealed İn order to provide content validity of the scale. Items in sketch scale are evaluated by Assistant Professor Doctor Olcay Yilmaz. With expert's opinion, some items are removed from the scale and numbers of the items in scale is increased to 100.

Construct validity: Construct validity indicates measurability degree correctly of a test. Factor analysis is used in order to examine construct validity of scale. Before the factor analysis, results of the KMO and Bartlett's Test are ,900 and meaningful. For KMO values is greater than 0,5 and Bartlett's test is meaningful, these show to be enough of suitability, factorability and sample size for component analysis.

After the factor analysis, while obtained values examine, having high value at only one factor, having load values at least $\mathrm{O}, 1$ of difference of two or more factor and load values should be greater than 0,45 . In a scale which include lots of factor, some factors which are greater than 0,45 are removed in scale. With resting of the 45 items, factor analysis is made again.

As a result of the principal component analysis, there are obtained 7 factors which are related to Attitude Towards to Flirting Violence. These are psychological violence, verbal violence, behavioural violence, physical violence, economic violence, social flirting violence and social media violence.

\section{KMO and Bartlett's Test}

\begin{tabular}{|c|c|c|}
\hline \multicolumn{2}{|c|}{ Kaiser-Meyer-Olkin Measure of Sampling Adequacy. } & 900 \\
\hline \multirow[t]{3}{*}{ Bartiett's Test of Sphericity } & Approx. Chi-Square & 6020,014 \\
\hline & $d f$ & 990 \\
\hline & Sig. & 0,000 \\
\hline
\end{tabular}

The values of KMO is ,900. This shows that this data is well suited for factor analysis. Because, values of KMO should be greater than 0,5. Also, Bartlett's test is meaningful. So, these values indicate that it is used excellently in a factor analysis.

\section{Communalities}

All the values in initial part are 1 and there are some different values in extraction. This extraction values indicates the proportion of variance for each variable that can be explained by the factors. So, extraction values should be greater than 0,4 . In this case, looking at these extraction values, they are greater than 0,4 . So, these values in extraction part are good extraction values for a factor analysis. The highest is md55 $(, 846)$ and the lowest is md35 (,404).

\section{Total Variance Explained}

\begin{tabular}{|c|c|c|c|c|c|c|c|c|c|}
\hline \multirow[b]{2}{*}{ Component } & \multicolumn{3}{|c|}{ Initial Eigenvalues } & \multicolumn{3}{|c|}{$\begin{array}{l}\text { Extraction Sums of Squared } \\
\text { Loadings }\end{array}$} & \multicolumn{3}{|c|}{$\begin{array}{l}\text { Rotation Sums of Squared } \\
\text { Loadings }\end{array}$} \\
\hline & Total & \begin{tabular}{|l|}
$\%$ of \\
Variance
\end{tabular} & $\begin{array}{l}\text { Cumulative } \\
\%\end{array}$ & Total & $\begin{array}{l}\% \text { of } \\
\text { Variance }\end{array}$ & \begin{tabular}{|l|} 
Cumulative \\
$\%$
\end{tabular} & Total & $\begin{array}{l}\% \text { of } \\
\text { Variance }\end{array}$ & $\begin{array}{l}\text { Cumulative } \\
\%\end{array}$ \\
\hline 1 & 13,298 & 29,550 & 29,550 & 13,298 & 29,550 & 29,550 & 7,154 & 15,898 & 15,898 \\
\hline 2 & 5,634 & 12,520 & 42,070 & 5,634 & 12,520 & 42,070 & 6,349 & 14,109 & 30,008 \\
\hline 3 & 2,449 & 5,443 & 47,513 & 2,449 & 5,443 & 47,513 & 4,710 & 10,467 & 40,474 \\
\hline 4 & 2,089 & 4,643 & 52,156 & 2,089 & 4,643 & 52,156 & 3,301 & 7,336 & 47,810 \\
\hline 5 & 1,963 & 4,363 & 56,518 & 1,963 & 4,363 & 56,518 & 3,246 & 7,213 & 55,023 \\
\hline 6 & 1,767 & 3,927 & 60,445 & 1,767 & 3,927 & 60,445 & 2,410 & 5,355 & 60,377 \\
\hline 7 & 1,059 & 2,353 & 62,798 & 1,059 & 2,353 & 62,798 & 1,089 & 2,421 & 62,798 \\
\hline
\end{tabular}

This table 2

Table 2 indicates the amount of variance that's explained by the factors. To consider and interpret, values should be greater than 1 . In this table, there are seven components which are extracted in total initial eigenvalues and the cumulative percentage is 62,798 . So, these seven factors explained $62 \%$ of the variance in the data matrix.

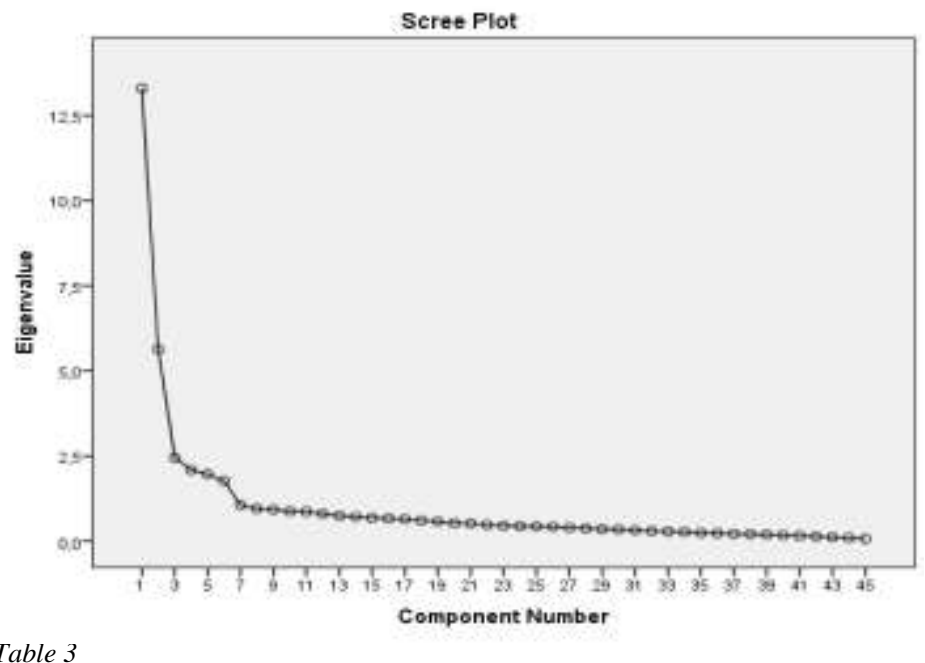

This scree plot separates two parts which are eigenvalue and component number in order to confirm how many factors. We can see that seven 
factors are above from 1 but other potential factors are below from 1 . So, they are not extracted.

\section{Component Matrix}

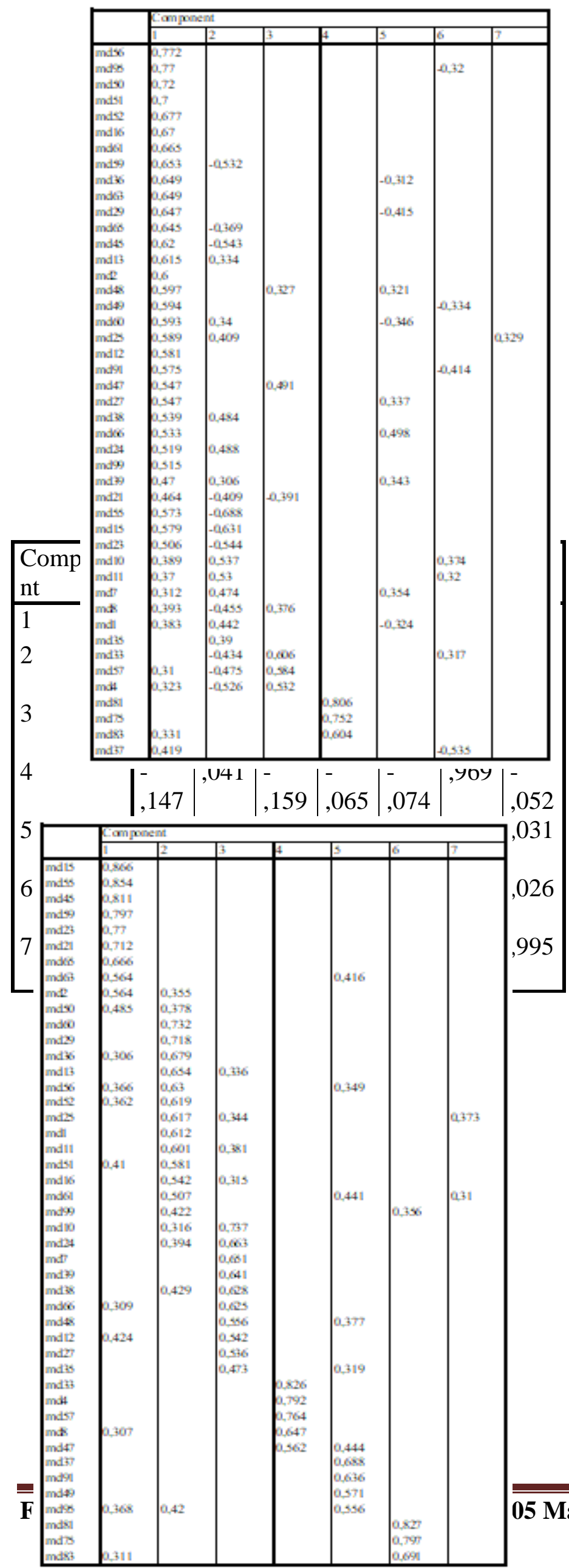

\section{The table 4}

Table 4 shows the loadings of the 45 variables on the 7 factors extracted. The higher the absolute value of the loading, the more the factor contributes to the variable. Empty place on the table represent loadings that are less than 0.5 , this makes reading the table easier.

\section{Rotated Component Matrix}

Table 5

The idea of rotation is to reduce the number factors on which the variables under investigation have high loadings. Rotation does not actually change anything but makes the interpretation of the analysis easier. In the table, while most of the variables are related to 1 factor before the rotation, after the rotation, variables are more balanced.

\section{Component Transformation Matrix
Table}

Component Transformation Matrix Factor defines the specific rotation which applied to the solution. Mathematically, when the factorial transformation matrix is multiplied by the factorial loads without rotation, the rotational factor loads are obtained.

\section{Evidences About The Reliability Of The Scale}

Cronbach's alpha is required to calculate the internal consistency coefficient of the 45-item scale. Cronbach's alpha is that the a (alpha) coefficient method developed by Cronbach. It is an internal consistency estimation method that should be used when the items are not scored correctly or incorrectly (Bademci, 2006). The Cronbach's alpha coefficient is an internal consistency finding formula that can be used in tests that have more than one answer choice " (Erkuş (2003:69)). As a result of this, the Cronbach's alpha coefficient can be used for all tests of the test items. (Worthen, White, Fan and Sudweeks, 1999). 
It is known that the Cronbach's alpha number is very reliable if it is between $0-0.2$, less reliable between 0.2-0.4, moderate reliable between 0.4-0.6, very reliable between $0.6-0.8$ and very reliable if 0.8-1.0. 231 people attended to our scale and as a result of the reliability of the scale, the consistency coefficient Cronbach's alpha was found to be 0.938 . According to the information of Cronbach's alpha, our scale is completely reliability.

\section{Discussion And Conclusion}

In this study, an attitude scale development process was carried out in order to determine the opinions of university students about their attitudes towards flirting violence. The validity and reliability study of the scale was made by reaching 232 TED University students from $18-25$ age range on the online platform. Within the scope of the validity study, factor analysis was performed to determine the validity of the draft scale. A substance that was found to be below the factor load value of 0.5 as a result of the factor analysis was extracted from the scale. When the results of the factor analysis were examined, it was seen that the scale had a sevenfactor structure. The variance explained by the seven-factor scale was $62,798 \%$.

The identified factors are called "psychological violence, verbal violence, behavioral violence, physical violence, economic violence, social flirting violence and social media violence". Under the first factor ten items $(10,31,24,34,13,12,38,37,2,28)$, under the second factor thirteen items $(35,17,20,9$, $32,30,15,1,7,29,11,36,45)$, under the third factor ten items $(6,14,4,23,22,39,26,8,16,19)$, under the fourth factor five items $(18,3,33,5,25)$, under the fifth factor four items $(21,43,27,44)$, under the sixth factor three items $(41,40,42)$ and the seventh factor is actually unreal like virtual. The Cronbach Alpha internal consistency coefficient calculated for the whole scale is 0.938 . Ten items which are under the first factor mostly indicate physical violence and verbal violence, thirteen items under the second factor mostly indicates social flirting violence, ten items which are under the third factor indicates social media violence, five factors under the fourth factor indicates behavioural violence, under the fifth factor four items indicate psychological violence and three items under the sixth factor indicates economic violence.

We would like to thank Assistant Professor Doctor Olcay Yulmaz for his contribution to the development of the scale.




[8] Interpretation of factor analysis using SPSS. (2017, July 26). Retrieved from https://www.projectguru.in/publications/inter pretation-of-factor-analysis-using-spss/

\section{References}

[1] Ayan, S., \& S. (n.d.). Aile içinde siddete uğrayan çocukların saldırganlık eğilimleri. Retrieved from https://issuu.com/sezerayan/docs/aile_i_ind e_siddete_u rayan ocu

[2] Cronbach'ın Alfası, Tek Boyutluluğun veya Benzeșikliğin ... (n.d.). Retrieved from http://dergipark.ulakbim.gov.tr/jcer/article/vi ew/5000039226\&p=DevEx.LB.1,5128.1

[3] Eğitim ve Psikolojiden Yansımalar | PDF | Çizgi Kitabevi. (n.d.). Retrieved from http://www.cizgikitabevi.com/kitap/576egitim-ve-psikolojiden-yansimalarpdf\&p=DevEx.LB.1,5539.1

[4] Factor Analysis I SPSS Annotated Output. (n.d.). Retrieved from https://stats.idre.ucla.edu/spss/output/factoranalysis/

[5] Faktör Analizi - yunus.hacettepe.edu.tr. (n.d.). Retrieved from http://yunus.hacettepe.edu.tr/ tonta/courses/f all2007/sb5002/sb5002-12-faktoranalizi.pdf \&p=DevEx.LB.1,5459.1

[6] Flört Şiddeti - uludagtipdergisi.org. (n.d.). Retrieved from http://www.bing.com/cr?IG=4734692C9721 4ECD9ECEE1839F60EC4D\&CID=0A326C 51F9A361F1103967A5F85E60FB\&rd=1\&h $=4$ ihHP0JOp-

0kNc1nS_KvWhfm10HemuvP4FqulM6TJd Y\&v=1\&r=http://uludagtipdergisi.org/pdf.ph p3?id=501\&p=DevEx.LB.1,5067.1

[7] FLÖRT ŞIDDETİ TUTUM ÖLÇEĞİ GEÇERLILIK VE GÜVENIRLILIIK ÇALIŞMASI - e-dergi.atauni.edu.tr. (n.d.). Retrieved from http://edergi.atauni.edu.tr/ataunihem/article/d
[9] İlköğretim Okul Yöneticilerinin Siddet Türlerine Yönelik ş ... (n.d.). Retrieved from http://dergipark.ulakbim.gov.tr/kuey/article/v iewFile/5000050505/5000047763\&p=DevEx .LB.1,5052.1

[10] Kocacik, F. (2001). Şiddet Olgusu Üzerine. Cumhuriyet Üniversitesi İ̈BF Dergisi (2).1, 1-7. Retrieved from http://dergipark.gov.tr/cumuiibf\&p=DevEx.L B.1,5521.1

[11] Lopez, V. A., \& Emmer, E. T. (2015, June 19). Influences of Beliefs and Values on Male Adolescents' Decision to Commit Violent Offenses. Retrieved from https://asu.pure.elsevier.com/en/publications/ influences-of-beliefs-and-values-on-maleadolescents-decision-to-

[12] Reha 9031222783 85. (n.d.). Güvenirliği Doğru Anlamak ve Bazı Klişeleri Yıkmak: Bilinenlerin Aksine, Cronbach'in Alfa Katsayıs1, Negatif ve "-1"den Küçük Olabilir. Retrieved from https://www.pegem.net/Akademi/3-8302Guvenirligi-Dogru-Anlamak-ve-BaziKliseleri-Yikmak-Bilinenlerin-AksineCronbach-8217-in-Alfa-Katsayisi-Negatifve-8220-8211-1-8221-den-KucukOlabilir.aspx

[13] Saldırganlığa Kuramsal Yaklaşım. (n.d.). Retrieved from http://www.psikolik.com/threads/saldırganlı̆ a-kuramsal-yaklașim.1290/

[14] Saldırganlığı Önlemeye Yönelik The Effect of Psycho-Education ... (n.d.). Retrieved from

http://dergisosyalbil.selcuk.edu.tr/susbed/arti cle/download/236/219\&p=DevEx.LB.1,5264 .1

[15] Sosyal Pekiştireçlerin ve Model Davranışlarının ... (n.d.). Retrieved from 
http://dergipark.gov.tr/download/articlefile/302359\&p=DevEx.LB.1,5293.1

[16] Sosyolojide Şiddet Kavramı Nazar Bal Ankara. (2015, December 14). Retrieved from https://paperzz.com/doc/5042129/--6--sosyolojide-șiddet-kavramı-nazar-bal-ankara

[17] Üniversite Öğrencilerinin Flört Şiddetine Yönelik Tutum ve Davranışları. (n.d.). Retrieved from http://genclikbirikimi.org/kunye-33616universite-ogrencilerinin-flort-siddetineyonelik-tutum-davranislari-tez 